\title{
Effect of Temperature and Time Torrefaction on the Energetic Properties of Bracatinga Wood
}

\author{
Iasmin Panzarini Silva ${ }^{1}$, Matheus Moraes e Silva ${ }^{1}$, Gilmara de Oliveira Machado ${ }^{1}$, \\ Victor Almeida de Araujo², Diogo Aparecido Lopes Silva ${ }^{3}$, \\ André Luis Christoforo ${ }^{4, *}$, Francisco Antonio Rocco Lahr ${ }^{5}$
}

\begin{abstract}
${ }^{1}$ Department of Forestry, State University of Midwest (UNICENTRO), Irati, Brazil
${ }^{2}$ Research Group LIGNO of UNESP-Itapeva, Department of Forest Sciences, School of Agriculture Luiz de Queiroz of University of São Paulo (ESALQ/USP), Piracicaba, Brazil

${ }^{3}$ Department of Production Engineering, Federal University of São Carlos (UFSCar), São Carlos, Brazil

${ }^{4}$ Centre for Innovation and Technology in Composites (CITeC), Department of Civil Engineering (DECiv), Federal University of São Carlos (UFSCar), São Carlos, Brazil

${ }^{5}$ Department of Structures Engineering (SET), Engineering School of São Carlos of University of São Paulo (EESC/USP), São Carlos, Brazil
\end{abstract}

\begin{abstract}
Torrefaction of Bracatinga wood was realized to determine the effect of temperature $\left(200^{\circ} \mathrm{C}, 220^{\circ} \mathrm{C}\right.$ and $\left.240^{\circ} \mathrm{C}\right)$ and time (30 $\mathrm{min}, 60 \mathrm{~min}$ and $90 \mathrm{~min}$ ) on its energetic properties. We found that the gravimetric yield of torrefied wood decreased from $99.27 \%$ to $85.60 \%$. The heat treatment at $240^{\circ} \mathrm{C}$ for 60 min produced the less hygroscopic sample as evidenced by an equilibrium moisture content of $37 \%$ lower than fresh wood (control sample). In addition, torrefaction produced samples of higher fixed carbon and lower levels of volatile content, reaching a maximum increase of $21 \%$ and decrease of $9 \%$, respectively. As the most important, the gross calorific value of terrified wood is about $5 \%$ higher than control. The increase of fixed carbon together with the reduction of both moisture and volatiles content show that this thermal treatment improve the energy content of torrefied wood that becomes a promising option for biofuels.
\end{abstract}

Keywords Heat treated wood, Biomass combustion, Exotic wood species

\section{Introduction}

In Brazil Bracatinga (Mimosa scabrella Benth.) has a natural occurrence in the Southeastern and South regions. It is a fast growing species and can be harvested to use directly as fuel or transformed in charcoal. Bracatinga is mainly used as firewood for domestic cooking stoves in rural areas and heating boilers in small industries [1-3].

The potential energetic of bracatinga's wood can be increased by applying heat. Torrefaction is a mild pyrolysis that promotes a controlled thermal degradation of wood, and happing at lower temperature (from 200 to $280^{\circ} \mathrm{C}$ ) than carbonization (from 300 to $700^{\circ} \mathrm{C}$ ) [4].

Torrefaction produces a solid biofuel that has its properties between wood and charcoal and retaining approximately $70 \%$ of the initial mass. The torrefied wood has hydrophobic properties and a higher calorific value than the fresh wood. Fresh wood has about 50\% and 10\% lower energy content than charcoal and torrified wood,

* Corresponding author:

alchristoforo@gmail.com.br (André Luis Christoforo)

Published online at http://journal.sapub.org/ijaf

Copyright (C) 2017 Scientific \& Academic Publishing. All Rights Reserved respectively. Thus, submit wood to heat is a method that modifies its chemical and physical properties to obtain a biomass fuel with a higher energetic density.

The torrefaction causes chemical changes in the constituents of cell wall (cellulose, hemicelluloses and lignin) and extractives. The extractives, which are compound by a wide range of organic substances of low molecular mass, evaporate rapidly when exposed to heat. Additionally, among the macromolecules and having a relative lower thermal stabilities, the high hydrophilic hemicelluloses are the most affected by heat than other constituents of wood, as cellulose and lignin. As lignin is the highest thermal stable macromolecule, it is the less affected by heat, and therefore contributes to increase the energy content because the lignin is the most energetic macromolecule of the wood [5].

Furthermore, the thermal treatment promotes the desacetylation of hemicelluloses that produces acetic acid, which act as a depolymerization catalyst of polysaccharides. The hemicelluloses degradation can lead to darkness of the wood fuel. During heat process, the dehydrating of hemicelluloses induces the formation of furfural and hidroximetifurfural, the latter compound contribute to the darkness of the wood $[1,6]$. 
Under heat effect, crystalline cellulose increases because of the degradation of amorphous cellulose and additionally the hemicelluloses decomposed almost completelly; as a result, the accessibility of the hydroxyl groups to the water molecules decrease and the moisture content of heat treated wood is lower. The lower moisture content produce a better fuel by decreasing the transport cost and turning the torrified wood more resistant to attack by rot fungi [7].

For energetic purposes, the main goals of this research is to investigate and compare the changes in chemical and physical properties of heat treated wood of Bracatinga at temperatures of 200,220 and $240{ }^{\circ} \mathrm{C}$; and time of 30,60 and $90 \mathrm{~min}$. For better understanding how the heat treatment affects the Calorific value of bracatingas's wood, we are using the results of the Approximate Analyses (fix carbon, volatile compounds and ash content), gravimetric yield, and equilibrium moisture content.

\section{Material and Methods}

The specie selected for the present investigation was Bracatinga (Mimosa scabrella). The trees were obtained from a farm plantation belong to the Forest College in Irati city, São Paulo state, Brazil. To have representative samples, the wood was collected by cutting boards from a trunk and the boards were then cut into test-pieces.

The heat treatment was carried out in a laboratorial Ética electric furnace, model 400.4. Eleven pieces of wood, with dimensions of $2 \mathrm{~cm}$ length, $3 \mathrm{~cm}$ width and $5 \mathrm{~cm}$ thick, were used by each treatment in the temperature at 200,220 and $240^{\circ} \mathrm{C}$ and in the times at 30,60 and $90 \mathrm{~min}$. The time of each treatment was recorded after reaching the required temperature.

Determination of the equilibrium moisture content: the test pieces were heated in the oven at $100 \pm 3^{\circ} \mathrm{C}$ until the mass constant. The measure was done in three times by each treatment, using the following equation:

$$
\mathrm{U}_{\mathrm{eq}}=\left[\left(\mathrm{m}_{\mathrm{i}}-\mathrm{m}_{\mathrm{s}}\right) / \mathrm{m}_{\mathrm{i}}\right] \cdot 100
$$

where: The initial mass is $m_{i}$ and the dry mass is $m_{s}, U_{e q}$ is the equilibrium moisture content from the conditioned test piece in a climated room under temperature at $20.5^{\circ} \mathrm{C} \pm 3.45$ and relative humidity at $73.8 \% \pm 6.80$.

Gravimetric yield: After cooling the test-pieces in a desiccator, the torrefied wood was weighed and determined the gravimetric yield as follow:

$$
\mathrm{R}_{\mathrm{g}}=\left(\mathrm{m}_{\mathrm{r}} / \mathrm{m}_{\mathrm{nr}}\right) \cdot 100
$$

where $m_{r}$ is the dry mass of the torrefied test-pieces and $m_{n r}$ is the dry mass of non-heated test-pieces.

Immediate analysis: the Immediate analysis of a fuel provides the percentage of volatile matter, fixed carbon and ash. The torrified and non-torrified samples were ground and sieved, and the material used was obtained after sieving with a particle size between 40 and 60 mesh. To determine the volatile content, $1.0 \mathrm{~g}$ of moisture-free sawdust was placed in a crucible with a lid and Heated in the oven at $600^{\circ} \mathrm{C}$ for 10 minutes, according to [8]. The fixed carbon content (FCC) is an indirect measurement and was calculated by the equation:

$$
\mathrm{FCC}(\%)=100-(\mathrm{AC}+\mathrm{CVM})
$$

were $\mathrm{AC}$ is the ash content and $\mathrm{CVM}$ is the content of volatile materials.

The test for determining the ash was conducted in a muffle oven at $700^{\circ} \mathrm{C}$ for 6 hours and calculated as follow:

$$
\mathrm{R}_{\mathrm{g}}=\left(\mathrm{m}_{\mathrm{r}} / \mathrm{m}_{\mathrm{i}}\right) \cdot 100
$$

where $m_{r}$ is the residue after heat process and $m_{i}$ is the initial dry mass.

Estimation of Heat Power: the gross calorific value (PCS $\mathrm{kcal} / \mathrm{kg}$ ) of torrefied and non-torrefied wood was estimated using data from the Immediate analysis, according the following equation proposed by [6] (Equation 5).

$\mathrm{PCS}=84.5104 \cdot \mathrm{CF}+37.2601 \cdot \mathrm{CV}+1.8642 \cdot \mathrm{CZ}$

Being CF the Fixed Carbon content, CV the content of Volatile fraction and $\mathrm{CZ}$ the content Ash content.

\section{Results and Discussions}

Wood is composed of polysaccharides (cellulose and hemicellulose) and lignin, which are responsible for their physical and chemical properties. The torrefaction promotes changes in these variables. Figure 1 illustrates the results of gravimetric yield referring to the nine treatments.

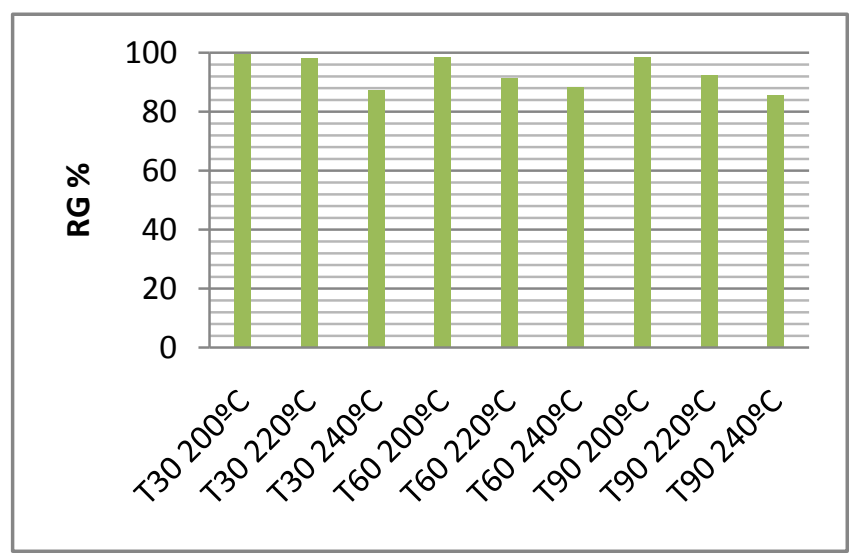

Figure 1. gravimetric yield resulting from the torrified process at T30 $200^{\circ} \mathrm{C}$, T30 $220^{\circ} \mathrm{C}$ and $\mathrm{T} 30240^{\circ} \mathrm{C}$ (samples treated for $30 \mathrm{~min}$ at 200,220 and $240^{\circ} \mathrm{C}$ respectively); T60 $200^{\circ} \mathrm{C}$, T60 $220^{\circ}$ and T60 $240^{\circ} \mathrm{C}$ (samples treated for $60 \mathrm{~min}$ at 200,220 and $240^{\circ} \mathrm{C}$ respectively); and, $\mathrm{T} 90200^{\circ} \mathrm{C}$, T90 $220^{\circ} \mathrm{C}$ and $\mathrm{T} 90240^{\circ} \mathrm{C}$ (samples treated for $90 \mathrm{~min}$ at 200,220 and $240^{\circ} \mathrm{C}$, respectively)

The torrefaction leads to a decrease in mass of wood, mainly due to thermal degradation of the hemicelluloses that decompose and release volatile compounds. Thus with the increasing of time and temperature treatment, it occurs a maximum of $14 \%$ reduction in gravimetric yield from $99.27 \%$ (sample $\mathrm{T} 30200^{\circ} \mathrm{C}$ ) to $85,60 \%$ (sample $\mathrm{T} 90$ $240^{\circ} \mathrm{C}$ ) Table 1. 
Table 1. Gravimetric yield (Rg), Equilibrium moisture content (Ueq) and Higher Calorific Value (PCS) of torrified and non-torrified wood

\begin{tabular}{|c|c|c|c|}
\hline Properties & $\mathbf{R}_{\mathrm{g}}(\%)$ & $\mathbf{U}_{\mathrm{eq}}(\%)$ & PCS (kcal/kg) \\
\hline Reference & --- & $10.23 \pm 0.4 \mathbf{a}(3.88 \%)$ & $4795.33 \pm 22.48$ cd $(0.47 \%)$ \\
\hline T30200 & $99.27 \pm 1.03$ a $(1.04 \%)$ & $10.56 \pm 0.27 \mathbf{a}(2.58 \%)$ & $4780.67 \pm 29.50 \mathrm{~cd}(0.62 \%)$ \\
\hline T30220 & $98.43 \pm 1.10$ a $(1.12 \%)$ & $9.43 \pm 0.71$ abc $(7.55 \%)$ & $4568.00 \pm 40.93 \mathbf{f}(0.90 \%)$ \\
\hline T30240 & $87.81 \pm 13.10$ b $(14.92 \%)$ & $8.22 \pm 0.84$ bcd $(10.17 \%)$ & $4920.33 \pm 33.86 \mathbf{b}(0.69 \%)$ \\
\hline T60200 & $98.44 \pm 0.66 \mathbf{a}(0.67 \%)$ & $9.64 \pm 0.28 \mathbf{a b}(2.91 \%)$ & $4798.00 \pm 9.64 \mathbf{c d}(0.20 \%)$ \\
\hline T60220 & $91.48 \pm 9.83 \mathbf{a b}(10.75 \%)$ & $8.00 \pm 0.41 \mathrm{~cd}(5.16 \%)$ & $4755.67 \pm 34.53$ cde $(0.73 \%)$ \\
\hline T60240 & $89.54 \pm 3.81 \mathbf{b}(4.26 \%)$ & $6.45 \pm 0.33$ e $(5.17 \%)$ & $4865.67 \pm 38.37$ bc $(0.79 \%)$ \\
\hline T90200 & $98.36 \pm 0.69 \mathbf{a}(0.70 \%)$ & $10.42 \pm 0.72 \mathbf{a}(6.93 \%)$ & $4748.00 \pm 28.51$ de $(0.60 \%)$ \\
\hline T90220 & $91.26 \pm 6.60 \mathbf{a b}(7.23 \%)$ & $7.81 \pm 0.52 \mathrm{de}(6.67 \%)$ & $4648.00 \pm 43.00$ ef $(0.93 \%)$ \\
\hline T90240 & $85.60 \pm 4.86 \mathbf{b}(5.68 \%)$ & $6.42 \pm 0.20$ e $(3.18 \%)$ & $5064.00 \pm 77.54 \mathbf{a}(1.53 \%)$ \\
\hline
\end{tabular}

The means followed by the same letter are not statistically different. Tukey's test was applied at the level of $5 \%$ probability.

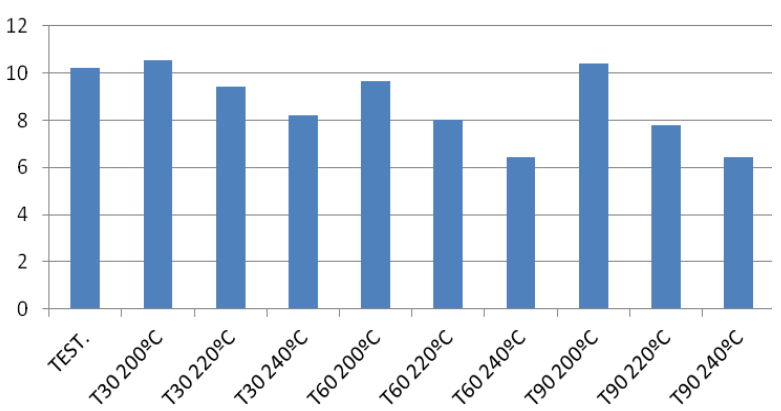

(a)

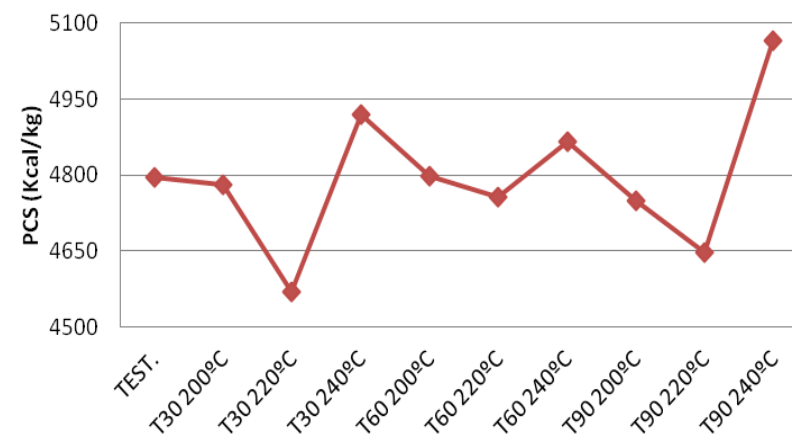

(b)

Figure 2. Equilibrium moisture content (a), calorific power higher of terrified samples including the reference condition (control) (b)

Regarding the hygroscopicity of the torrefied samples, Table 1 and Figure 1 show the results of variance analysis and graph related to experimental design. The equilibrium moisture content values tend to decreased when the temperature and time increase, so there is a variation in the hygroscopic properties of the wood with the heat treatment. The hemicelluloses are very hygroscopic components of wood, its degradation promotes a reduction in the capacity of wood to absorb ambient water; consequently, providing a reduction in the equilibrium moisture content with a maximum reduction of $37 \%$ than the control sample, in the temperature at $240^{\circ} \mathrm{C}$ and time at $30 \mathrm{~min}$.
The Torrefaction increased the energy content of bracatinga wood (Figure 2). Fuels from biomass with higher fixed carbon content and consequently lower volatile content are those with the highest energy content, Table 2.



Figure 3. Immediate composition of terrified and non-torrified samples

The samples treated for longer times and temperatures have higher fixed carbon content, the treatment of $90 \mathrm{~min}$ at $240^{\circ} \mathrm{C}$ has an increase of $21 \%$ in carbon content than the control sample as well as lower volatile levels, decrease of 9\%, Table 2 and Figure 2.

\section{Conclusions}

These results indicated that torrefaction increases the energy content of Bracatinga wood making it more suitable for applications such as fuel in heating plants whose power supply comes from biomass burning.

The samples treated for longer times and temperatures showed lower hygroscopicity, as evidenced by a lower equilibrium moisture content: reduction of $37 \%$ compared to control, at the temperature of $240^{\circ} \mathrm{C}$ and time of $30 \mathrm{~min}$; as well as the higher carbon content fixed ( $21 \%$ increase) and lower volatile content (decreased 9\%).

As the most important factor, it was found that the gross calorific value increased in 5\% with increasing temperature and roasting time. 
Table 2. Composition of Immediate data (CV is the volatile content, $\mathrm{CF}$ is the fixed carbon content and the $\mathrm{CZ}$ the ash content) and Higher Calorific Value (PCS) of terrified and non terrified wood

\begin{tabular}{|c|c|c|c|c|}
\hline & CV $(\%)$ & CF (\%) & $\mathrm{CZ}(\%)$ & PCS (kcal/kg) \\
\hline Reference & $75.75 \pm 0.48 \mathbf{a b}(0.64 \%)$ & $23.32 \pm 0.48 \mathbf{c d}(2.07 \%)$ & $0.93 \pm 0.08 \mathbf{a b}(8.31 \%)$ & $4795.33 \pm 22.48 \mathbf{c d}(0.47 \%)$ \\
\hline T30200 & $\begin{array}{c}75.64 \pm 0.63 \mathbf{a b c} \\
(0.83 \%)\end{array}$ & $\begin{array}{c}23.19 \pm 0.63 \mathbf{c d} \\
(2.70 \%)\end{array}$ & $\begin{array}{c}1.17 \pm 0.20 \mathbf{a b} \\
(17.32 \%)\end{array}$ & $\begin{array}{c}4780.67 \pm 29.50 \mathbf{c d} \\
(0.62 \%)\end{array}$ \\
\hline T30220 & $\begin{array}{c}76.45 \pm 0.85 \mathbf{a} \\
(1.11 \%)\end{array}$ & $\begin{array}{c}20.24 \pm 0.87 \mathbf{e} \\
(4.30 \%)\end{array}$ & $\begin{array}{c}3.22 \pm 1.94 \mathbf{a} \\
(60.09 \%)\end{array}$ & $\begin{array}{c}4568.00 \pm 40.93 \mathbf{f} \\
(0.90 \%)\end{array}$ \\
\hline T30240 & $\begin{array}{c}73.24 \pm 0.71 \mathbf{c} \\
(0.98 \%)\end{array}$ & $\begin{array}{c}25.92 \pm 0.71 \mathbf{b} \\
(2.76 \%)\end{array}$ & $\begin{array}{c}0.85 \pm 0.18 \mathbf{b} \\
(21.16 \%)\end{array}$ & $\begin{array}{c}4920.33 \pm 33.86 \mathbf{b} \\
(0.69 \%)\end{array}$ \\
\hline T60200 & $\begin{array}{c}74.98 \pm 0.21 \text { abc } \\
(0.27 \%)\end{array}$ & $\begin{array}{c}23.69 \pm 0.21 \text { bed } \\
(0.87 \%)\end{array}$ & $\begin{array}{c}1.34 \pm 0.07 \mathbf{a b} \\
(5.09 \%)\end{array}$ & $\begin{array}{c}4798.00 \pm 9.64 \mathbf{c d} \\
(0.20 \%)\end{array}$ \\
\hline T60220 & $\begin{array}{c}76.64 \pm 0.73 \mathbf{a} \\
(0.95 \%)\end{array}$ & $\begin{array}{c}22.46 \pm 0.73 \text { de } \\
(3.25 \%)\end{array}$ & $\begin{array}{c}0.89 \pm 0.03 \mathbf{a b} \\
(3.22 \%)\end{array}$ & $\begin{array}{c}4755.67 \pm 34.53 \text { cde } \\
(0.73 \%)\end{array}$ \\
\hline T60240 & $\begin{array}{c}73.89 \pm 0.81 \mathbf{b c} \\
(1.10 \%)\end{array}$ & $\begin{array}{c}24.98 \pm 0.81 \mathbf{b c} \\
(3.24 \%)\end{array}$ & $\begin{array}{c}1.14 \pm 0.02 \mathbf{a b} \\
(2.17 \%)\end{array}$ & $\begin{array}{c}4865.67 \pm 38.37 \mathbf{b c} \\
(0.79 \%)\end{array}$ \\
\hline T90200 & $\begin{array}{c}75.91 \pm 0.60 \mathbf{a b} \\
(0.79 \%)\end{array}$ & $\begin{array}{c}22.68 \pm 0.60 \mathbf{c d} \\
(2.66 \%)\end{array}$ & $\begin{array}{c}1.41 \pm 1.03 \mathbf{a b} \\
(72.85 \%)\end{array}$ & $\begin{array}{c}4748.00 \pm 28.51 \mathrm{de} \\
(0.60 \%)\end{array}$ \\
\hline T90220 & $\begin{array}{c}75.38 \pm 0.92 \mathbf{a b c} \\
(1.22 \%)\end{array}$ & $\begin{array}{c}21.70 \pm 0.92 \text { de } \\
(4.23 \%)\end{array}$ & $\begin{array}{c}2.92 \pm 0.77 \mathbf{a b} \\
(26.30 \%)\end{array}$ & $\begin{array}{c}4648.00 \pm 43.00 \text { ef } \\
(0.93 \%)\end{array}$ \\
\hline T90240 & $\begin{array}{c}68.96 \pm 1.64 \mathbf{d} \\
(2.38 \%)\end{array}$ & $\begin{array}{c}29.49 \pm 1.64 \mathbf{a} \\
(5.57 \%)\end{array}$ & $\begin{array}{c}1.56 \pm 1.10 \mathbf{a b} \\
(71.00 \%)\end{array}$ & $\begin{array}{c}5064.00 \pm 77.54 \mathrm{a} \\
(1.53 \%)\end{array}$ \\
\hline
\end{tabular}

[5] Modes, K.S. Effect of thermal grinding on the physical-mechanical and biological properties of Pinus taeda and Eucalyptus grandis wood. Dissertation (Master in

\section{REFERENCES}

[1] Sturion, J. A.; Tomaselli, I. Influence of the storage time of Bracatinga wood in the production of energy. Boletim de Pesquisa Florestal, Colombo, n. 21, p.37-47, dez. 1990.

[2] Brito, J. O.; Cintra, T.C. Wood for energy in Brazil: reality, strategic vision and demand for actions. Biomassa \& Energia, v. 1, n. 2, p. 157-163, 2004.

[3] Cortez, L. A. B.; Lora, E. E. S.; Gómez, E. O. Biomass for energy. Campinas: Unicamp, 2009.

[4] Figueroa, M. J. M. Influence of temperature on the mechanical resistance of Paricá. Dissertation (Master in Civil Engineering) - Federal University of Santa Catarina, Brazil, 2008. Maria, Brazil, 2010.

[6] Parikh, J.; Channiwala, S. A.; Ghosal G.K. A correlation for calculating HHV from proximate analysis of solid fuels. Fuel. v. 84, p. 487-494, 2005.

[7] Rodrigues, T. O. Effects of torrefaction on the biomass conditioning for energy purposes. Dissertation (Master in Forestry Sciences) - University of Brasília, Brazil, 2009.

[8] American Society for Testing and Materials - ASTM E711. Standard Test Method for Gross Calorific Value of Refuse-Derived Fuel by the Bomb Calorimeter. ASTM, 2012. 